\title{
MOBIL ROBOT MOZGÁSÁNAK VEZÉRLÉSE
}

\author{
Cservenák Ákos \\ PhD hallgató, Miskolci Egyetem, Szerszámgépészeti és Mechatronikai Intézet, Robert Bosch Mechatronikai \\ Intézeti Tanszék \\ 3515 Miskolc, Miskolc-Egyetemváros, e-mail: cservenak.akos@uni-miskolc.hu
}

\begin{abstract}
Absztrakt
Manapság az Ipar 4.0 hatására az iparban is megjelentek a vezetö nélküli jármüvek, így a szállitótargoncák is. Ezen jármüvek automatizálása manapság is sokrétü feladat. Jelen cikk feladata egy ilyen jármü poziciójának vizsgálata és mozgásának tervezése. A vezetö nélküli szállitótargonca a Miskolci Egyetem Logisztikai Intézetének High-Tech laboratóriumában található. A targonca az ottani anyagmozgatási rendszer része. A jármü pozícióját a LIDAR szenzor segitségével érzékeli. A cikk ismerteti a különbözö helyzetekben mért pozíciók sorozatát, valamint részletez egy mozgás tervezési lehetöséget.
\end{abstract}

Kulcsszavak: mechatronika, mobil robot, autonóm jármü, trajektória tervezés

\begin{abstract}
Nowadays, following Industry 4.0 the driverless vehicles have appeared in the industry, such as the carriers. Automating these vehicles is a difficult task also nowadays. The purpose of this article is to plan the motion of such a vehicle. A driverless carrier or AGV can be found in the High-Tech Laboratory of the Institute of Logistics at the University of Miskolc. The vehicle is part of a material handling system. The vehicle's position is detected by a LIDAR sensor. The article describes a series of measured positions in various situations, furthermore details a motion planning option.
\end{abstract}

Keywords: mechatronics, mobile robot, autonomous vehicle, trajectory planning

\section{Bevezetés}

Manapság az Ipar 4.0 hatására az iparban is megjelentek a vezető nélküli járművek, így a szállítótargoncák is, amelyek AGV-nek (Automated Guided Vehicle) [1], vagy mobil robotnak tekinthetö [2]. Az anyagmozgatási gépeket túlnyomórészt manapság is emberi erőforrás irányítja. Jelen cikk egy vezető nélküli szállítótargonca pozíciómérési lehetőségeit vizsgálja, és bemutat egy egyszerü pályatervezési lehetőséget. Egy ilyen jármü a Miskolci Egyetem Logisztikai Intézetében levő High-Tech laboratórium anyagmozgatási rendszerének része [4]. A pozíció meghatározására különböző technológiák állnak rendelkezésre [5], mint például induktív szenzor [6-8], képfeldolgozás [9,10], vagy LIDAR. A vizsgált jármủ pozícióját egy LIDAR szenzor segítségével érzékeli és virtuális pályát használ, mint a [11]-ben kifejlesztett AGV.

A cikk 2. fejezete ismerteti a már említett targoncát, kitérve fontosabb elemeire és tulajdonságaira. A pozíciómérés során tapasztalt különböző eredményeket mutatja be a 3. fejezet. A 4. fejezet röviden ismerteti egy targonca pályatervezési lehetőséget. Az 5. fejezet végül összefoglaló megállapításokat tesz a cikkben elért eredményekröl. 


\section{Vezető nélküli targonca}

A Bevezetésben említett vezető nélküli targoncát a Gamma Digital Kft. készítette 2009-ben [3]. A targoncatípusok közül ezt a targoncát szállítótargoncának lehet nevezni, hiszen található rajta két darab tárolófelület, amelyek szállítószalagként is funkcionálnak. A targonca az anyagmozgatási rendszerben különböző állomások között képes mozogni [4]. A bejövő áruhelynél felveszi az árut, elviszi a görgőspályarendszer valamelyik állomásához, és ott leadja az árut. Ugyanezt a mozgást ellentétes irányban is meg tudja tenni. Nem csak két állomás található a rendszerben, így a targonca több különböző útvonalon is közlekedhet.

A targoncán a következő fontosabb elemek találhatók:

- LIDAR Navigáció,

- 6 szabadságfokú ipari robot,

- szállítószalag,

- biztonsági érzékelők,

- PLC és PC,

- 30V DC hajtómotorok, 1:25 áttétel,

- beálló kerék.

A navigációról részletesebben a 3. fejezetben esik szó. Az ipari robot egy Mitsubishi márkájú RV2SDB típusú robot, amely képes darabáruk manipulálására.

A szállítószalag egységrakomány átadásával és elvételével képes a laboratóriumban található görgöspálya rendszerrel kapcsolatba lépni.

A targonca elején és hátulján található Sick márkájú biztonsági érzékelők hivatottak a környezet érzékelésére. Az érzékelőknek két zónája van: figyelmeztető zóna, ekkor még nem áll meg a targonca, ezt az adatot fel lehet használni programozás során; valamint a tiltási zóna, ahol az érzékelő egy relé segítségével bontja a motorokra jutó áramellátást, ezáltal rögtön megáll a targonca.

A PLC a targoncán található egyszerúbb kimeneti és bemeneti adatok kezeléséért, a PC pedig a mozgásért felelős algoritmus futtatásért és az ehhez szükséges matematikai számításokért felelős. A PC feladata ezeken felül a hajtómotorok és szállítószalag motorok vezérlése párhuzamos porton keresztül.

A hajtómotorok $30 \mathrm{~V}$ egyenáramú feszültségüek, amelyek egyenként 1:25 áttételü hajtóművön keresztül hajtják a kerekeket. A két kerék hajtása független egymástól, így differenciális hajtásról beszélhetünk. A targonca másik két kereke beálló kerék.

Az egyes, hálózatra is kapcsolható eszközök egy switch segítségével egymással, egy wifi bridge segítségével pedig a külvilággal is képesek kommunikálni az Ipar 4.0 IoT (Internet-of-Things) elvének megfelelve.

Az elemeken kívül fontos megemlíteni még a pályához kötöttséget: az ilyen targoncák általában valamilyen fizikai pályát követnek, mint például mágnescsíkot, vagy mágnespontokot, illetve optikai nyomvonalkövetés a jellemző még. A vizsgált targonca viszont virtuális pályán halad, a pozicionáláshoz csak a LIDAR navigációt használja.

\section{Vezető nélküli targoncán végzett pozíciómérések}

A targonca pozíciójának méréséért a 2. fejezetben már említett LIDAR navigációs egység felelős, ami Sick márkájú NAV350 típusú egység. Ez a navigációs egység egy forgó fejen keresztül lézerfényt 
bocsát ki, és a helyiségben elhelyezett speciális fényvisszaverö tükrök segítségével kiszámolja az egység X, Y pozícióját és elfordulási szögét. A koordinátarendszer nullpontját egy szoftver segítségével kell beállítani. A navigációs egység továbbítja a PC felé X, Y koordinátákat és szögértékeket, és ez alapján lehet pozícióalapú vezérlést kialakítani, valamint különböző pozícióméréseket végezni.

A fejezet 3 különböző mérést ismertet:

- a targonca egyhelyben áll,

- a targonca $1 \mathrm{db}$ egyenes vonalú, oda-vissza mozgása $X=0-1000 \mathrm{~mm}$ között,

- a targonca $5 \mathrm{db}$ egyenes vonalú, oda-vissza mozgása $\mathrm{X}=0-1000 \mathrm{~mm}$ között.

\subsection{Pozíciómérés - targonca egyhelyben áll}

A mérés során a targonca nem mozog, így elméletileg az $\mathrm{X}$ és $\mathrm{Y}$ pozíciók változatlanok. A mérések során azonban megállapítható, hogy a mért érték változik $X$ irányban $9 \mathrm{~mm}-\mathrm{t}$, $\mathrm{Y}$ irányban $7 \mathrm{~mm}-\mathrm{t}$, ahogy az 1. ábrán látható. A szenzor mérési pontossága a gyári katalógus szerint $\pm 10 \mathrm{~mm}$.

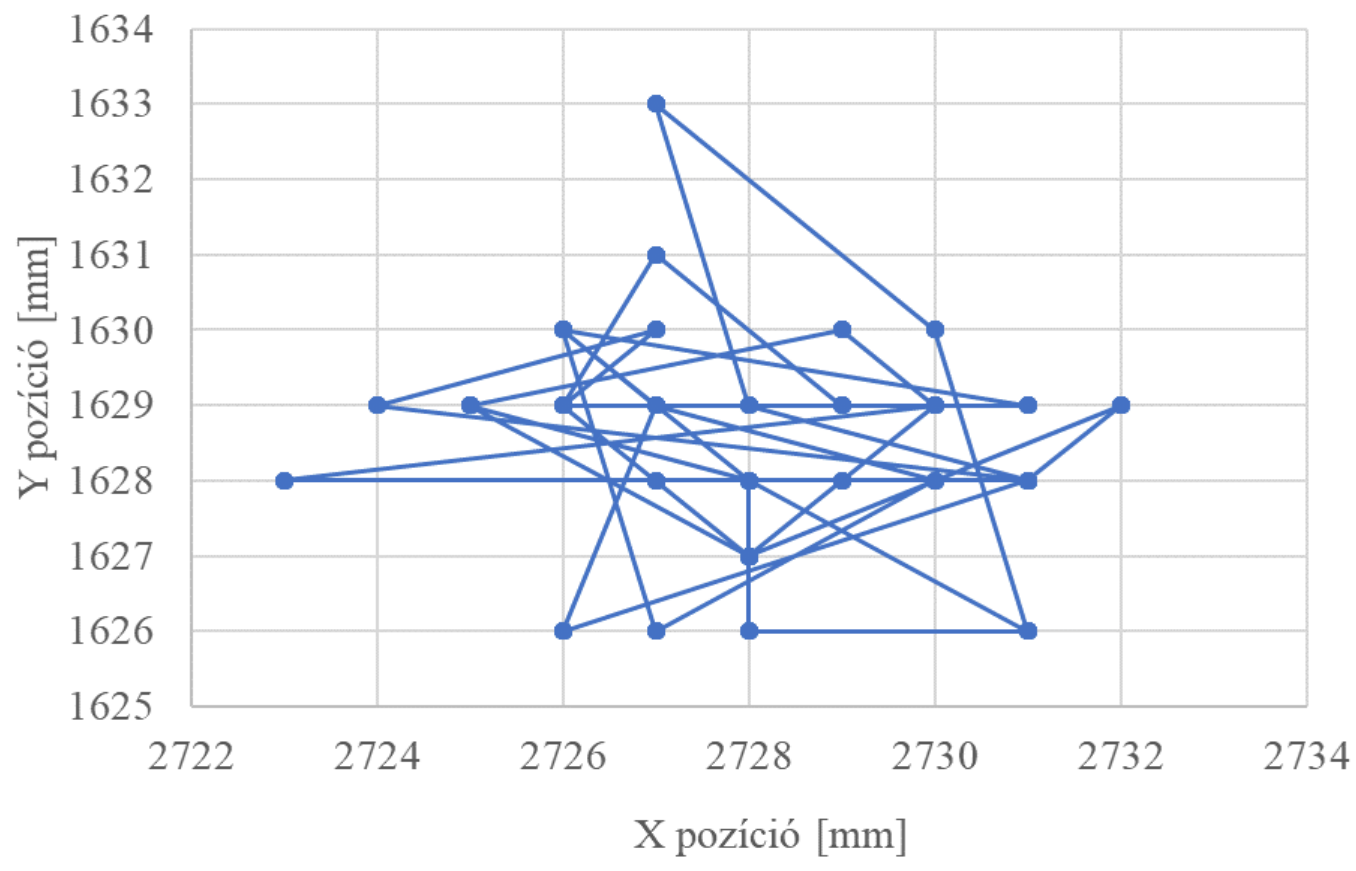

1.ábra. Mért X és Y pozíciók - targonca egyhelyben áll

\subsection{Pozíciómérés - $1 \mathrm{db}$ egyenes vonalú, oda-vissza mozgása $X=0-1000 \mathrm{~mm}$ között}

A mérés során a targonca $1 \mathrm{db}$ egyenes vonalú oda-vissza mozgást végez, így elméletileg két egyenesnek kellene adódnia. A mérések során azonban megállapítható, hogy a 3.1. fejezetben részletezett mérési eredmény változása mellett a targonca sem tökéletesen egy vonalban mozog, ahogy a 2. ábrán látható. A targonca irányváltása során a beálló kerék elfordulása miatt a targonca kis mértékben kitér az egyenes vonaltól. Ezen kívül a kerék és talaj közötti felületi egyenetlenségek is befolyásolják a targonca mozgását. 


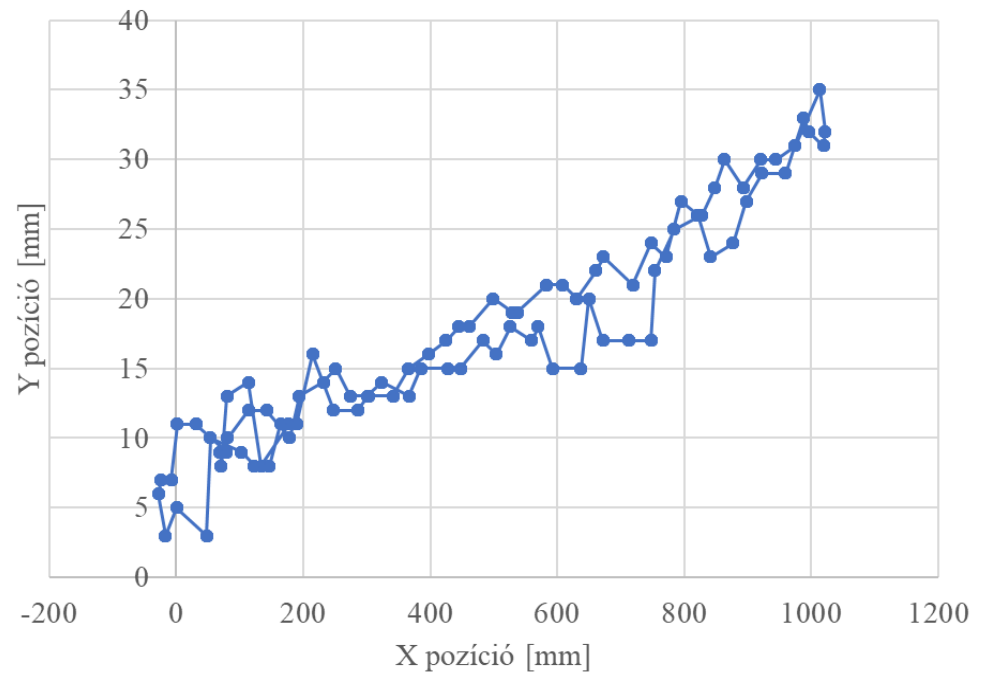

2.ábra. Mért X és Y pozíciók - 1 db egyenes vonalú, oda-vissza mozgása X=0-1000mm között

\subsection{Pozíciómérés - $5 \mathrm{db}$ egyenes vonalú, oda-vissza mozgása $X=0-1000 \mathrm{~mm}$ között}

A mérés során a targonca $5 \mathrm{db}$ egyenes vonalú oda-vissza mozgást végez, így elméletileg 10 , egymást fedő egyenesnek kellene adódnia. A mérések során azonban megállapítható, hogy a 3.1 és 3.2. fejezetben részletezett okok mellett a targonca nem ugyanazt a vonalat követi, ahogy a 3. ábrán látható. A targonca irányváltása során a beálló kerék elfordulása miatt a targonca nemcsak kitér az egyenes vonaltól, hanem a szögelfordulása is változik minden egyes oda-vissza mozgás során.

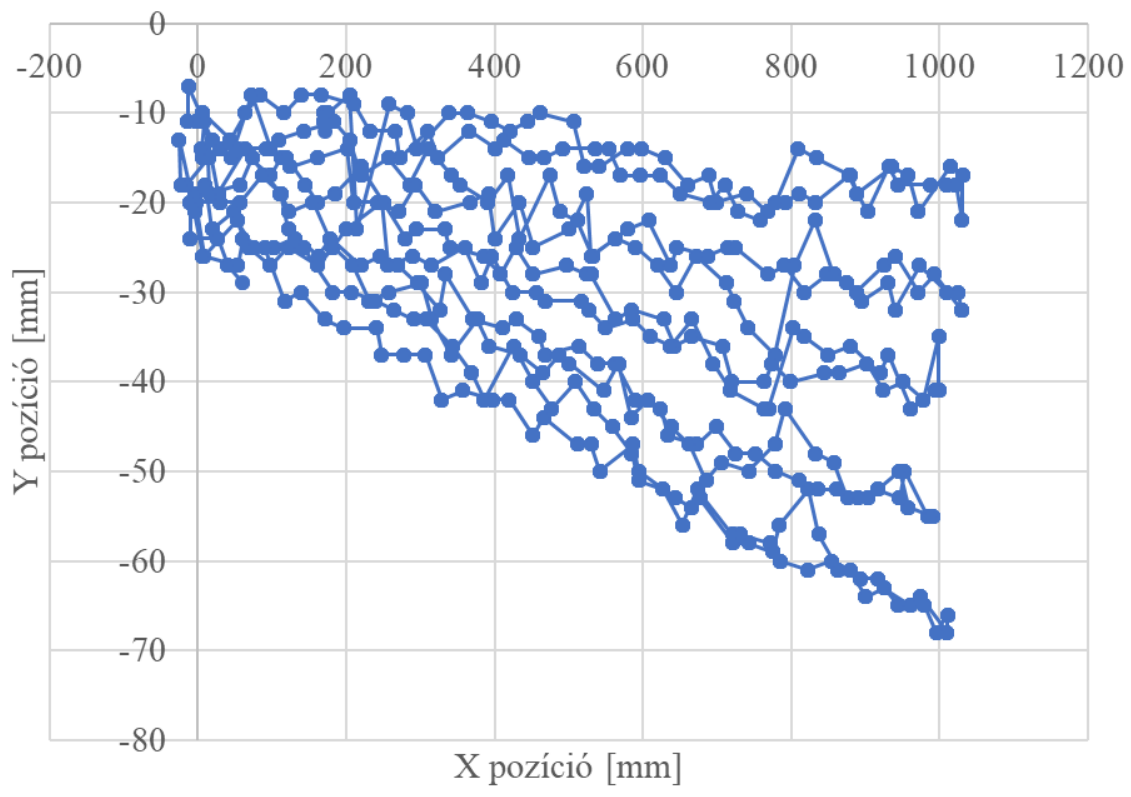

3.ábra. Mért X és Y pozíciók-5 db egyenes vonalú, oda-vissza mozgása X=0-1000mm között 


\section{Pályatervezési lehetőség}

Egy targonca mozgásának tervezése során az egyik cél a kiinduló pont és végpont közötti útvonaltervezés. Az útvonalat szegmensekre kell felosztani annak érdekében, hogy az egyenes és íves szakaszok váltakozása megtörténhessen, valamint nyomon követhető legyen a targonca pályája. A tervezés során figyelembe kell venni:

- gyorsítást, lassítást elindulás, megállás során,

- gyorsítást, lassítást kanyarodás során.

A mozgás tervezésre egy példa látható a 4 . ábrán.

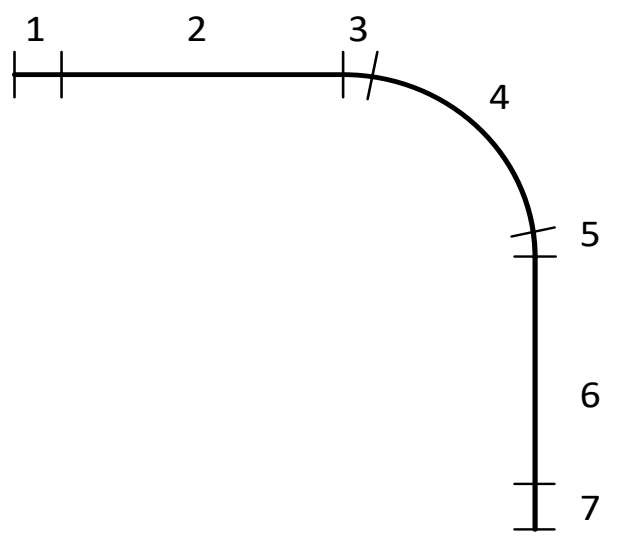

4.ábra. Példa a targonca pályájának szegmensekre való felosztására

A 4. ábrán egy egyszerü, derékszögben való kanyarodást mutat be. A pálya összesen 7 szegmenst tartalmaz:

1. gyorsítás 0 sebességről az elöírt sebességre,

2. egyenletes haladás az elöírt sebességen,

3. egyik kerék lelassul a kanyarodás végrehajtása érdekében,

4. egyenletes, íven történő haladás,

5. a lassabb kerék ismét felgyorsul az egyenletes haladás érdekében,

6. egyenletes haladás az elöírt sebességen,

7. lassítás az előírt sebességről 0 sebességre.

\section{5. Összefoglalás}

Megállapítható, hogy a navigációs eszköz gyárilag elöírt pontossága és a beálló kerék hatása miatt a mérések során nem egyenletes értékek alakultak ki, az egyes vizsgált eseményeknél különböző módon. Végül a 4. fejezet egy targonca mozgás tervezésének egyik lehetséges módját mutatja be egy példán illusztrálva.

\section{Köszönetnyilvánítás}

A cikkben ismertetett kutató munka az EFOP-3.6.1-16-2016-00011 jelủ „Fiatalodó és Megújuló Egyetem - Innovatív Tudásváros - a Miskolci Egyetem intelligens szakosodást szolgáló intézményi fejlesztése" projekt részeként - a Széchenyi 2020 keretében - az Európai Unió támogatásával, az Európai Szociális Alap társfinanszírozásával valósul meg. 


\section{Irodalom}

[1] Müller, T.: Automated Guided Vehicles, IFS (Publications) Ltd, UK, Springer-Verlag, Berlin, Heidelberg, New York, ISBN 3-540-12629-5 (1983).

[2] Edwards, M.: The Difference Between AGVs and Mobile Robots, Cross Company (2016), https://www.crossco.com/blog/difference-between-agvs-and-mobile-robots

[3] Papp, Á., Szilassy, L., Sárosi, J.: Navigation of differential drive mobile robot on predefined, software designed path, Recent Innovations in Mechatronics (RIIM), Debrecen (2016). https://doi.org/10.17667/riim.2016.1-2/3.

[4] Skapinyecz, R., Illés, B.: Introduction of the High-Tech Logistics Laboratory installed at the Institute of Logistics of the University of Miskolc, COMEC 2019, Cuba

[5] Vale, A., Ventura, R., Lopes, P., Ribeiro, I.: Assessment of navigation technologies for automated guided vehicle in nuclear fusion facilities, Robotics and Autonomous Systems (2017). https://doi.org/10.1016/j.robot.2017.08.006

[6] Petriu, E.M., Basran, J.S., Groen, F.C.A.: Automated guided vehicle position recovery, IEEE Transactions on Instrumentation and Measurement 39(1), 254-258 (1990). https://doi.org/10.1109/19.50460

[7] Petriu, E.M.: Automated guided vehicle with absolute encoded guide-path, IEEE Transactions on Robotics and Automation 7(4), 562 - 565 (1991). https://doi.org/10.1109/70.86087

[8] Cox, I.J.: Blanche-an experiment in guidance and navigation of an autonomous robot vehicle, IEEE Transactions on Robotics and Automation 7(2), 193-204 (1991). https://doi.org/10.1109/70.75902

[9] Francis, S. L. X., Anavatti, S. G., Garratt, M., Shim, H.: A ToF-camera as a 3D Vision Sensor for Autonomous Mobile Robotics, International Journal of Advanced Robotic Systems (2015). https://doi.org/10.5772/61348

[10] Kelly, A., Nagy, B., Stager, D., Unnikrishnan, R.: An Infrastructure-Free Automated Guided Vehicle Based on Computer Vision, IEEE Robotics \& Automation Magazine (2007).

[11] Bačík, J., Durovský, F., Biroš, M., Kyslan, K., Perduková, D., Sanjeevikumar, P.: Pathfinder Development of Automated Guided Vehicle for Hospital Logistics, IEEE Access (2017). https://doi.org/10.1109/ACCESS.2017.2767899 